\title{
Automotive Lithium-ion Cell Manufacturing: Regional Cost Structures and Supply Chain Considerations
}

Donald Chung, Emma Elgqvist, and Shriram Santhanagopalan Clean Energy Manufacturing Analysis Center (CEMAC)

Technical Report

NREL/TP-6A20-66086

April 2016

Contract No. DE-AC36-08G028308 


\section{Automotive Lithium-ion Cell Manufacturing: Regional Cost Structures and Supply Chain Considerations}

Donald Chung, Emma Elgqvist, and Shriram Santhanagopalan Clean Energy Manufacturing Analysis Center (CEMAC)

Prepared under Task No. VTP2.6B01

Clean Energy Manufacturing Analysis Center 15013 Denver West Parkway Golden, CO 80401 303-275-3000

www.manufacturingcleanenergy.org
CEMAC is operated by the Joint Institute for Strategic Energy Analysis for the U.S. Department of Energy's Clean Energy Manufacturing Initiative.
Technical Report

NREL/TP-6A20-66086

April 2016

Contract No. DE-AC36-08GO28308 


\section{NOTICE}

This report was prepared as an account of work sponsored by an agency of the United States government. Neither the United States government nor any agency thereof, nor any of their employees, makes any warranty, express or implied, or assumes any legal liability or responsibility for the accuracy, completeness, or usefulness of any information, apparatus, product, or process disclosed, or represents that its use would not infringe privately owned rights. Reference herein to any specific commercial product, process, or service by trade name, trademark, manufacturer, or otherwise does not necessarily constitute or imply its endorsement, recommendation, or favoring by the United States government or any agency thereof. The views and opinions of authors expressed herein do not necessarily state or reflect those of the United States government or any agency thereof.

This report is available at no cost from the National Renewable Energy Laboratory (NREL) at www.nrel.gov/publications.

Available electronically at SciTech Connect: http:/www.osti.gov/scitech

Available for a processing fee to U.S. Department of Energy and its contractors, in paper, from:

U.S. Department of Energy

Office of Scientific and Technical Information

P.O. Box 62

Oak Ridge, TN 37831-0062

OSTI http://www.osti.gov

Phone: 865.576.8401

Fax: 865.576.5728

Email: reports@osti.gov

Available for sale to the public, in paper, from:

U.S. Department of Commerce

National Technical Information Service

5301 Shawnee Road

Alexandria, VA 22312

NTIS http://www.ntis.gov

Phone: 800.553 .6847 or 703.605 .6000

Fax: 703.605.6900

Email: orders@ntis.gov

Cover Photos: (left to right) iStock 2225189; iStock 16687273; Oak Ridge National Laboratory; iStock 24304597; iStock 26005993; iStock 2069560

NREL prints on paper that contains recycled content. 


\section{Abstract}

Manufacturing capacity for lithium-ion batteries (LIBs) - which power many consumer electronics and are increasingly used to power electric vehicles-is heavily concentrated in east Asia. Currently, China, Japan, and Korea collectively host $88 \%$ of all LIB cell and $79 \%$ of automotive LIB cell manufacturing capacity. Mature supply chains and strong cumulative production experience suggest that most LIB cell production will remain concentrated in Asia. However, other regions-including North America-could be competitive in the growing automotive LIB cell market under certain conditions. To illuminate the factors that drive regional competitiveness in automotive LIB cell production, this study models cell manufacturing cost and minimum sustainable price, and examines development of LIB supply chains and current LIB market conditions. Modeled costs are for large format, 20-Ah stacked pouch cells with lithium-nickel-manganese-cobalt-oxide (NMC) cathodes and graphite anodes suitable for automotive application. Production volume is assumed to be at commercial scale, $600 \mathrm{MWh}$ per year. 


\section{Table of Contents}

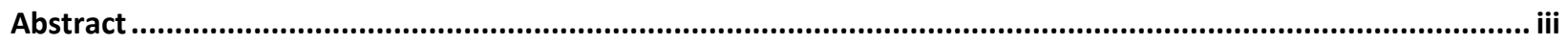

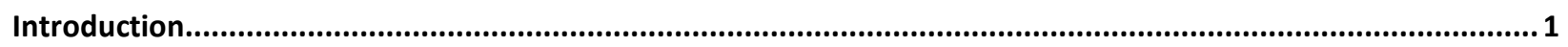

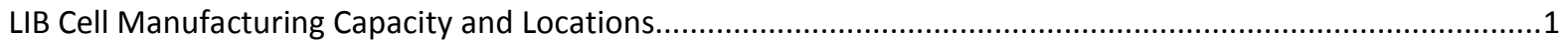

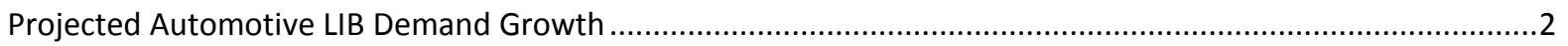

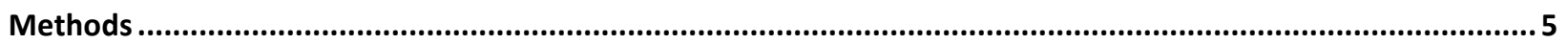

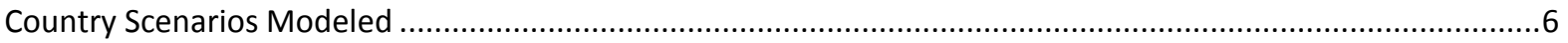

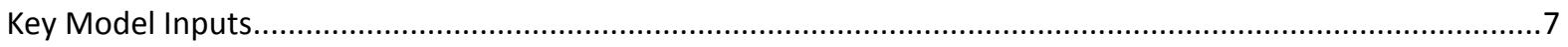

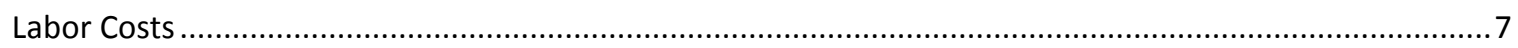

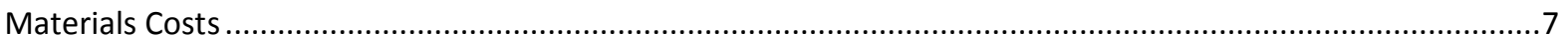

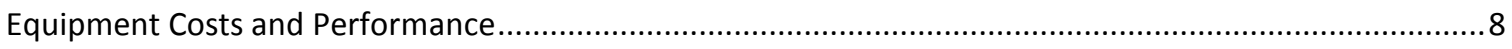

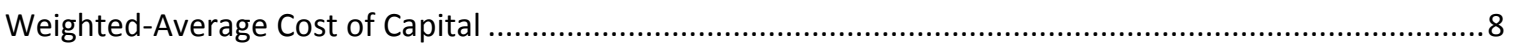

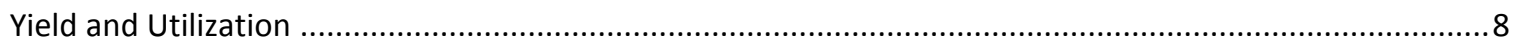

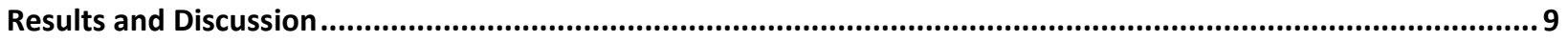

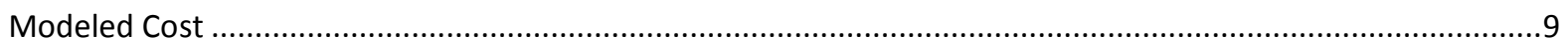

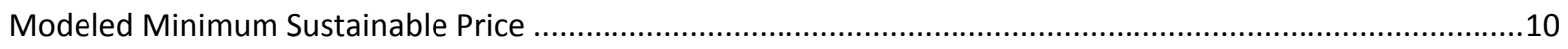

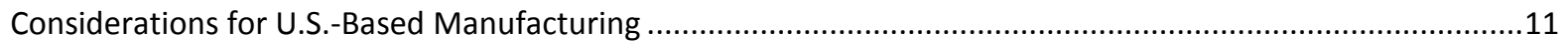

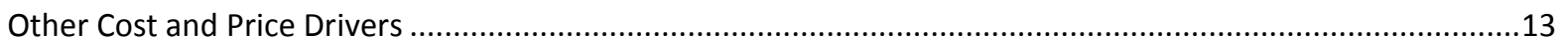

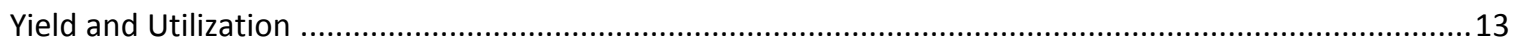

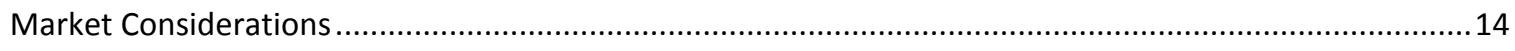

Cells in the Context of Total LIB Supply Chain .................................................................................. 14

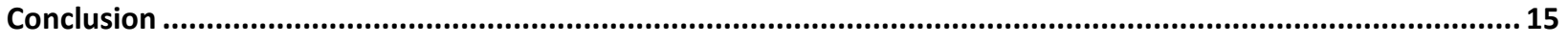

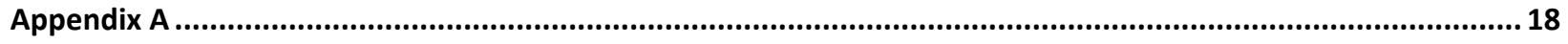

\section{List of Figures}

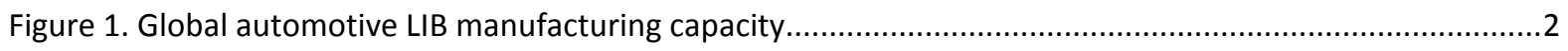

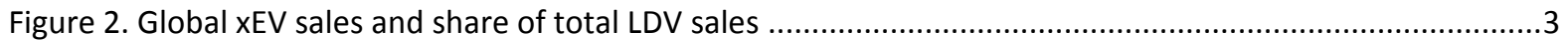

Figure 3. Estimated xEV LIB demand and global automotive LIB manufacturing capacity ................................4

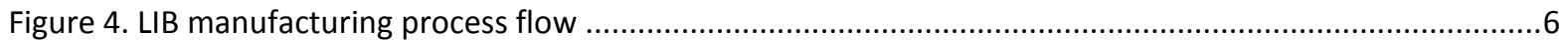

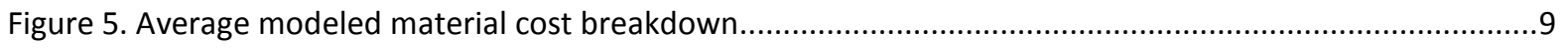

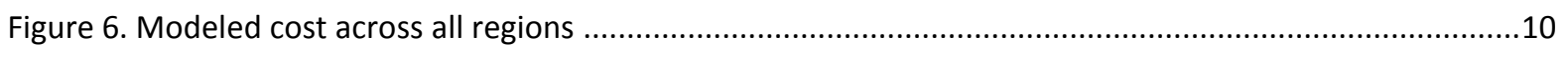

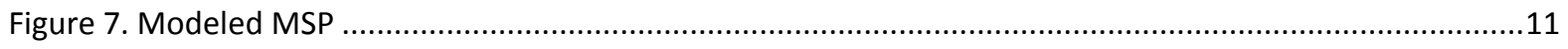

Figure 8. Modeled minimum sustainable price, U.S. Future scenario........................................................12

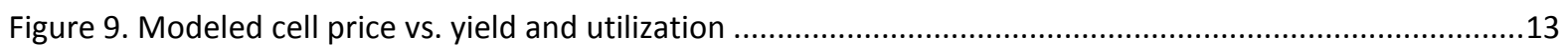

\section{List of Tables}

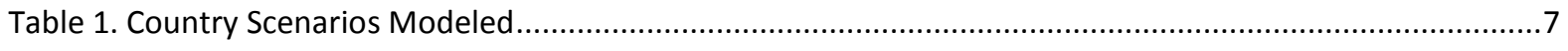

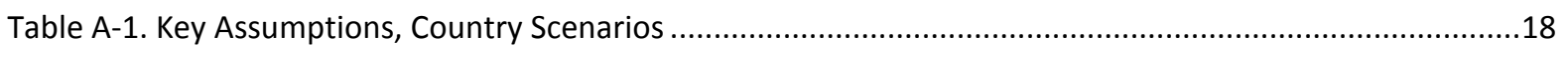

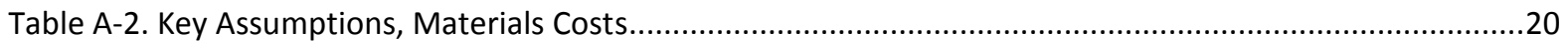




\section{Introduction}

\section{LIB Cell Manufacturing Capacity and Locations}

In 2015, the world's total LIB cell manufacturing capacity was primarily located in China, Japan, and Korea. Together, these countries hosted $88 \%$ of total global LIB cell manufacturing capacity for all end-use applications. ${ }^{1}$ These countries were also home to a significant share of LIBspecific materials manufacturing capacity, including that for cathodes ( $85 \%$ of global capacity), anodes $(97 \%)$, separators (84\%), and electrolytes (64\%). This concentration of cell manufacturing capacity and upstream supply chains contributes to LIB industrial clusters in each of these countries. Note that these numbers do not include the Tesla "gigafactory", which at the announced $35 \mathrm{GWh}$ manufacturing capacity will significantly alter the global manufacturing landscape (Tesla 2016).

The LIB manufacturing clusters in China, Japan, and Korea are a result of longstanding public and private investments in the LIB sector. For instance, Japan's concentration of LIB cell and upstream processed materials suppliers grew from sustained investments in LIB technology by consumer electronics companies in the 1990s. These companies saw promise in LIB technology for the impact that the higher energy densities enabled could have on the performance of their core portable electronic device businesses. The Japanese government bolstered private sector investments with R\&D funding and low-cost capital to establish manufacturing plants (Brodd 2012). Korea and China followed Japan's lead in investing in LIB cell and pack production for consumer electronics, and have created their own LIB production clusters. Korea's LIB cluster is a result of government and industry efforts, started in the 2000s, to build up this portion of the supply chain within Korea (Venkataraman and Gartner 2011; Alexander and Gartner 2013). China, too, has fortified its LIB cluster development through various government R\&D programs, tax incentives, investment incentives (Patil 2008), domestic content requirements, and export restraints (Haley 2012; Stewart 2012). While Korean and Chinese cell manufacturers initially relied heavily on Japanese suppliers, their national efforts to build LIB clusters have resulted in less dependence on Japanese suppliers (Venkataraman and Gartner 2011; Alexander and Gartner 2013), and may contribute to the advantageous pricing observed in these regions for key materials for fully scaled, co-located Korean and Chinese cell producers (Wessner and Wolff 2012).

\footnotetext{
${ }^{1}$ Capacities include facilities that are fully commissioned, partially commissioned, and under construction.
} 

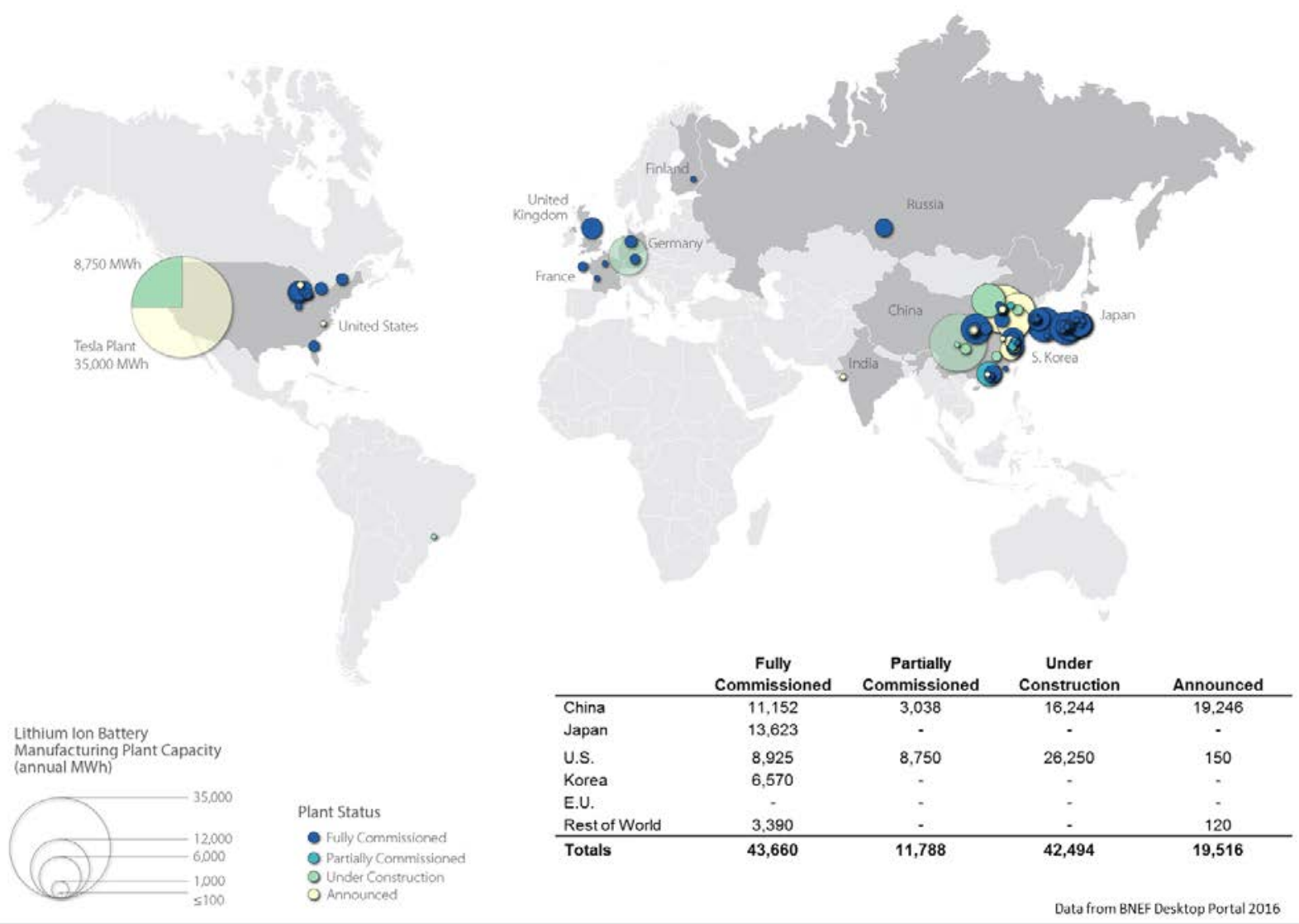

Figure 1. Global automotive LIB manufacturing capacity

Relative to these Asian manufacturers, the United States is home to an immature LIB supply chain, and most U.S. cell and battery plants are relatively new, though notably some are owned by firms with experience in battery production (e.g., LG Chem). However, the United States is a leading nation in automotive LIB production capacity, and currently hosts $20 \%$ of global automotive LIB cell capacity, surpassing the auto-specific share of early-mover Korea. Nearly all U.S.-based LIB capacity is targeted at serving the emerging automotive market. Global capacities by country for auto-specific LIB cell production are presented in Figure 1.

\section{Projected Automotive LIB Demand Growth}

We estimate automotive LIB demand will grow at a 36\% compound annual growth rate (CAGR) from 2015-2020 (using data from BNEF Desktop Portal 2016; Technavio Insights 2015; Shepard and Jerram 2015; Behl; 2015; IEA 2015; Davis et al. 2015), from 11 GWh in 2015 to 54 GWh in 2020 (Figure 3). The projected growth is driven by demand for electric vehicles including hybrid electric vehicles (HEVs), plug-in hybrid electric vehicles (PHEVs), and battery electric vehicles (BEVs) (collectively referred to as "xEVs"). Demand for xEVs in all geographic markets is sensitive to several key drivers, namely governmental requirements for fuel economy and/or emissions, governmental demand- and supply-side subsidies, the cost of xEV drivetrain technology, charging infrastructure, consumer preference, and the prices of gasoline and diesel. Electric vehicles of all types currently comprise only a small portion of the total light duty 
vehicle (LDV) market. Furthermore, many HEVs, which constitute a large portion of the xEV market, utilize nickel metal hydride (NiMH) batteries, not LIB (though this is beginning to change). However, xEV sales are expected to grow at a 44\% CAGR through 2020, as presented in Figure 2, whereas total LDV sales are forecast to grow at a 1.4\% CAGR over the same time period. Note, while 2015 is labeled as a forecast year, we include one actual data point for this year in our average, while all other sources reflect forecasts.

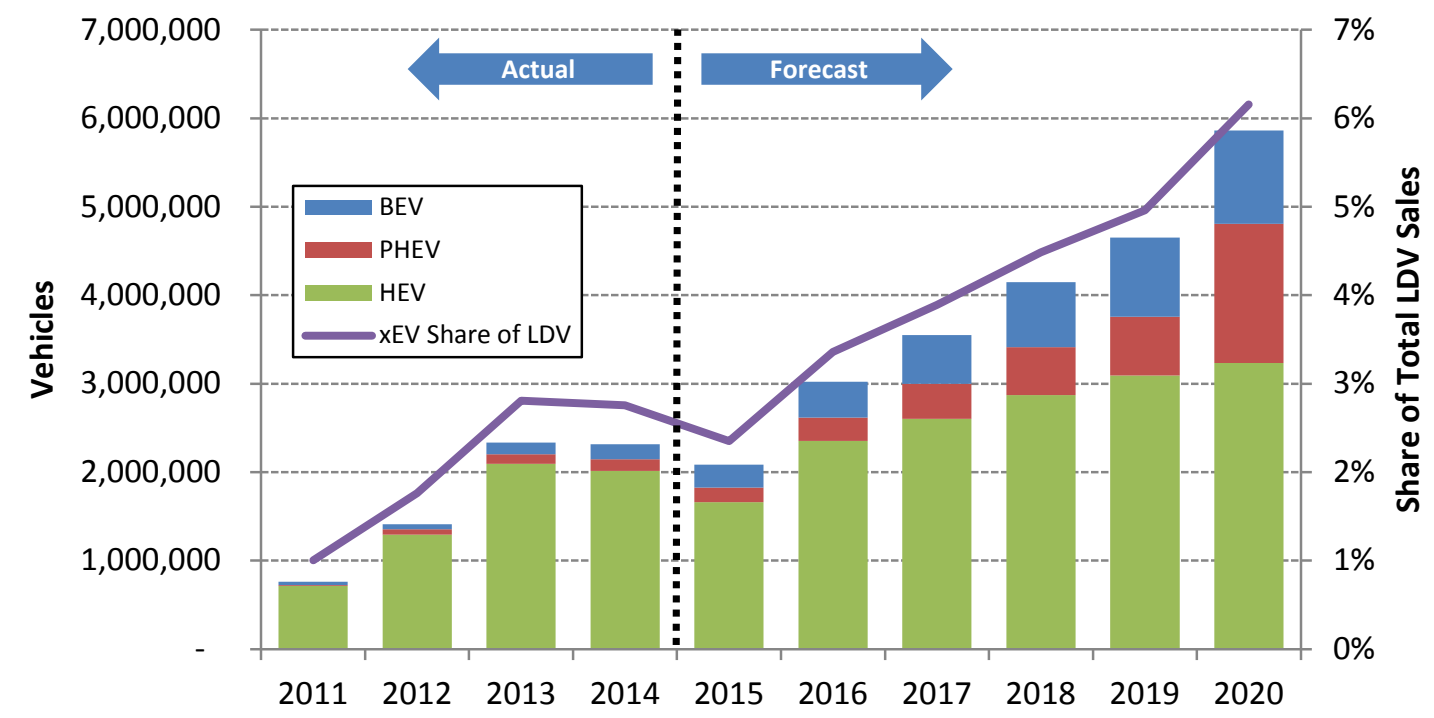

Figure 2. Global XEV sales and share of total LDV sales

Source: Average of data from BNEF Desktop Portal 2016; Technavio Insights 2015; Shepard and Jerram 2015; Behl 2015; Alexander and Gartner 2014; and IEA 2015

Initial overly optimistic assumptions regarding xEV demand (and BEV/PHEV demand, particularly) have contributed to an overbuild of large format LIB cell production capacity targeted at vehicle markets (Figure 3). Global average utilization was estimated at $22 \%$ at the beginning of 2014, and is expected to reach $40 \%$ in 2016 . While overcapacity conditions are improving, it is still likely exerting negative price pressures upon industry participants. If global capacity remains at 2016 levels, capacity and demand will come into better balance in the coming years, with the need for new capacity arising in 2019-2020. 


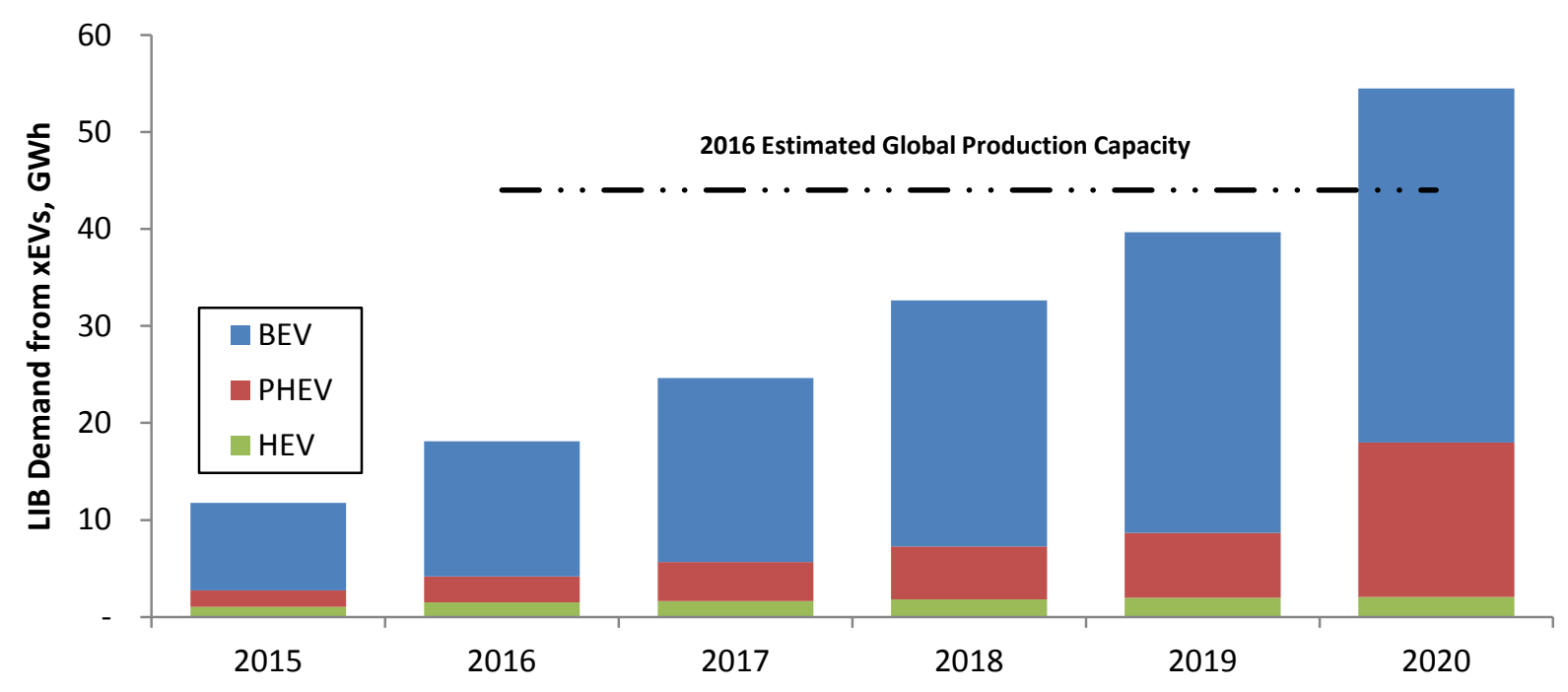

Figure 3. Estimated xEV LIB demand and global automotive LIB manufacturing capacity Source: Data from BNEF Desktop Portal 2016; Technavio Insights 2015; Shepard and Jerram 2015; Behl 2015; Davis et al. 2015; and IEA 2015

However, the data in Figure 1 suggests that capacity is likely to continue growing, and overcapacity conditions may persist. Nearly $55 \mathrm{GWh}$ of capacity is currently either partially commissioned or under construction, and a further $20 \mathrm{GWh}$ of capacity has been announced. 


\section{Methods}

The NREL cost model is based upon a detailed technical LIB cell production process model, enabling a bottom-up accounting of the total costs that a manufacturer incurs in the highvolume production of large format automotive LIB cells. The model quantifies performance parameters for each process step, including material consumption, energy consumption, labor requirements, equipment utilization, throughput, and yield. By then assigning estimates for all capital, fixed, and variable costs associated with each process step, an integrated technoeconomic model for LIB cell production is created. Finally, the model accounts for typical operating, research and development, and tax expenses incurred by an LIB manufacturing firm. This detailed technical and cost information is used to create an integrated pro forma financial model, from which a minimum sustainable price (MSP) can be determined using discounted cash flow methods (Powell 2013; Goodrich 2013). Conceptually, the MSP is the selling price that enables a manufacturer to realize an internal rate of return (IRR) equivalent to their weighted average cost of capital (WACC). This is a theoretical construct that attempts to represent a longterm price required for healthy, sustainable operations assuming the current WACC for a set of public firms engaged in the battery business. It is important to note that market forces dictate actual selling prices, which may not align with computed MSPs.

The model assumes that a new LIB cell manufacturing facility is built and operated throughout its useful life by a single firm. Modeled costs are for large format, 20-Ah stacked pouch cells with lithium-nickel-manganese-cobalt-oxide (NMC) cathodes and graphite anodes. Production volume is assumed to be 8.3 million cells (600 MWh) per year. A simplified process flow of the manufacturing process is shown in Figure $4 .^{2}$

\footnotetext{
2 Operational parameters and capital equipment costs derived from equipment manufacturers' information, interviews,
} and NREL estimates. 


\section{LIB Cell Production Process}

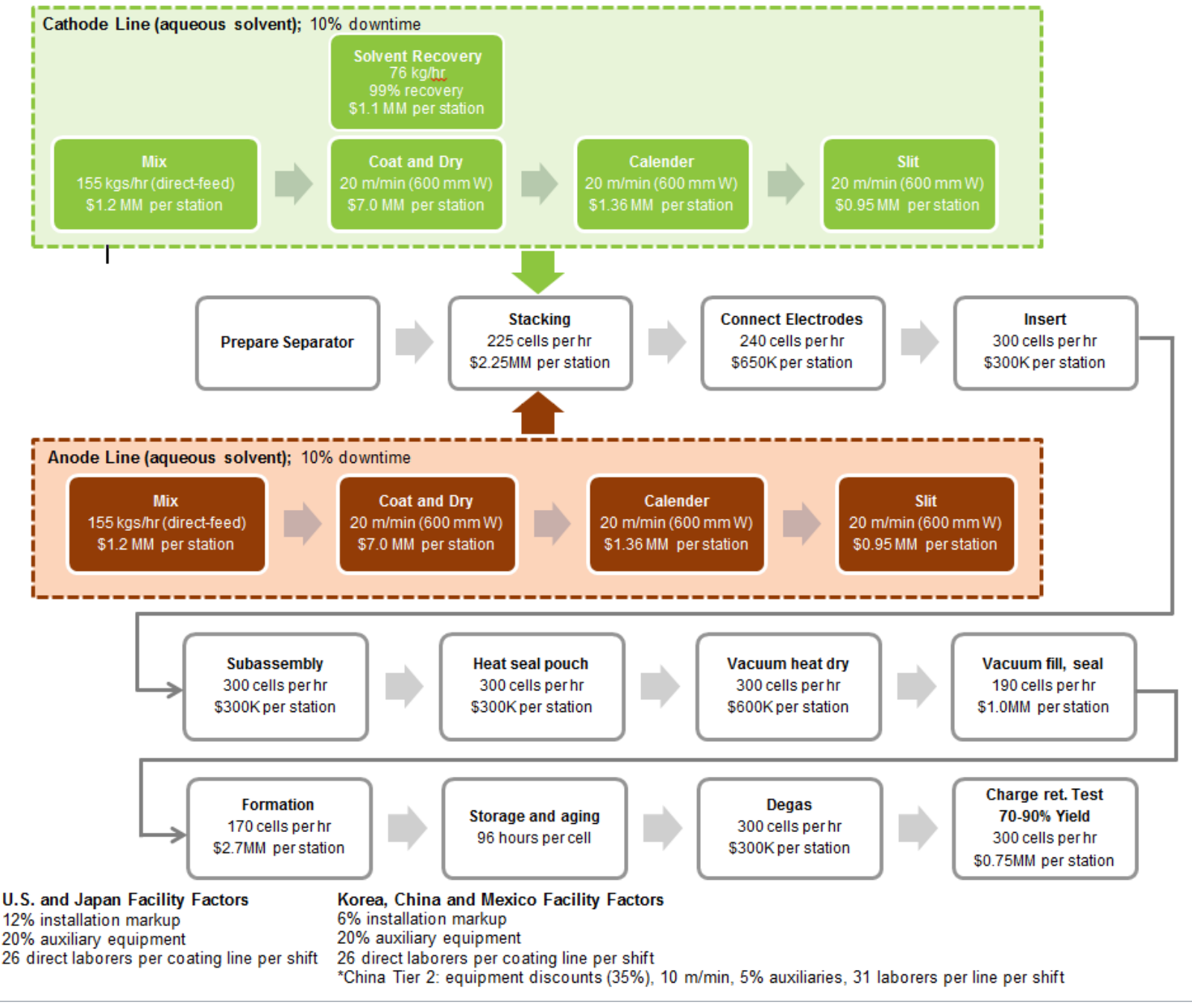

Figure 4. LIB manufacturing process flow

\section{Country Scenarios Modeled}

Representative scenarios are developed with the intent of benchmarking the performance of actual firms operating in the countries studied, while future scenarios are developed to understand the effects of various drivers upon the potential competitiveness of different country and firm scenarios and the risks and opportunities these may present. In modeling country scenarios, we assume that values for certain parameters are either wholly or in part country-specific. Country-specific values are utilized for parameters such as labor rates, energy costs, facilities costs, costs of capital, and 25 additional inputs (key scenario assumptions are included in the Appendix A. Eight country scenarios are developed as described in Table 1. 
Table 1. Country Scenarios Modeled

\begin{tabular}{|c|c|c|}
\hline Scenario & Description & $\begin{array}{l}\text { Company Domicile / } \\
\text { Manufacturing Location }\end{array}$ \\
\hline U.S. Startup ${ }^{1}$ & $\begin{array}{l}\text { Relatively new market entrant with focus on technology R\&D } \\
\text { through commercialization. }\end{array}$ & U.S. / U.S. \\
\hline $\begin{array}{l}\text { U.S. Transplant } \\
\text { (Korea) }{ }^{1}\end{array}$ & $\begin{array}{l}\text { U.S. manufacturing facility owned by a Korean corporate } \\
\text { parent with experience in automotive and consumer } \\
\text { electronics LIB. }\end{array}$ & Korea / U.S. \\
\hline Japan $^{1}$ & $\begin{array}{l}\text { Japanese firm with experience in automotive and consumer } \\
\text { electronics LIB. }\end{array}$ & Japan / Japan \\
\hline Korea $^{1}$ & $\begin{array}{l}\text { Korean firm with experience in automotive and consumer } \\
\text { electronics LIB. }\end{array}$ & Korea / Korea \\
\hline China Tier $1^{1}$ & $\begin{array}{l}\text { Chinese firm with experience in automotive and consumer } \\
\text { electronics LIB. }\end{array}$ & China / China \\
\hline China Tier $2^{1}$ & $\begin{array}{l}\text { Chinese firm with experience in automotive and consumer } \\
\text { electronics LIB. Firm employs less automated processes and } \\
\text { slightly lower quality materials. }\end{array}$ & China / China \\
\hline $\begin{array}{l}\text { Mexico } \\
\text { Transplant } \\
\text { (Japan) }^{2}\end{array}$ & $\begin{array}{l}\text { Mexican manufacturing facility owned by a Japanese } \\
\text { corporate parent with experience in automotive and consumer } \\
\text { electronics LIB. Combines Mexico region advantages with } \\
\text { incumbent firm advantages. }\end{array}$ & Japan / Mexico \\
\hline U.S. Future ${ }^{2}$ & $\begin{array}{l}\text { U.S. firm partnering with more experienced firms to produce } \\
\text { LIBs in the U.S. Combines U.S. region advantages with } \\
\text { incumbent firm advantages. }\end{array}$ & U.S. / U.S. \\
\hline
\end{tabular}

\section{Key Model Inputs \\ Labor Costs}

Labor rates for each country scenario are estimated using international wage data from the U.S. Bureau of Labor Statistics (BLS), with the exception of rates for China. BLS rates for China were as of 2012, but many regions within China have witnessed a rapid rise in labor rates for the past few years (Wall Street Journal 2014). Because of this growth, labor rates in China are approximately equal to-or possibly in excess of-those in Mexico today ("Mexico vs. China" 2014; “UPDATE 1" 2013; Coy 2013). The model makes the simplifying assumption of equivalent labor rates for China and Mexico.

\section{Materials Costs}

The model arrives at material costs for each scenario by applying a two-level breakdown of materials costs. First, general material prices are assumed to be lower for high-volume incumbent manufacturers based on purchasing volumes. All scenarios assume this volume discount for materials except the U.S. Startup scenario. Second, for certain materials (most critically cathode active materials) additional local production discounts are applied in the Korea and China scenarios, as it appears that particularly close supplier relationships, encouraged by overall national industry development objectives, could result in additional material cost advantage to LIB cell manufacturers located in these countries (Wessner and Wolff 2012). Further, in China, there are explicit domestic content requirements and export restraints that may contribute to lower materials costs for Chinese cell producers (Haley 2012; Stewart et al. 2012). 
For example, the Mexico scenario assumes an experienced Japanese corporate parent, and thus volume pricing discounts are applied to the Mexico scenario. However, the location-based material discount is not applied to this case, as the additional discount is assumed to be applicable only to manufacturers co-located with the materials suppliers in Korean or Chinese LIB industrial clusters.

\section{Equipment Costs and Performance}

The model incorporates all costs associated with each production step including installation of auxiliary equipment costs. Because installation costs are driven by labor rates, the effects of differences in labor rates across regions are compounded. Some process steps may require multiple stations, and equipment requirements per process steps vary depending on the annual production (number of cells) volume being modeled. Equipment performance parameters such as speed, throughput, labor requirements, material consumption, etc. are incorporated in the model.

\section{Weighted-Average Cost of Capital}

MSPs are derived by incorporating the modeled capital and operating costs into a discounted cash flow analysis, where cell sales at the MSP must generate sufficient return to cover the assumed cost of capital. Regional WACCs were estimated using a set of comparable firms domiciled and publicly traded on exchanges within each of the countries of interest. For the transplant cases (Korean transplant in the United States, Japanese transplant in Mexico), the cost of capital assumed was based upon comparable companies domiciled in the parent company's home country. The model appends an additional country risk premium (or discount) based upon the credit default swap spreads against sovereign bonds between the parent company's country of domicile and the manufacturing facility location.

\section{Yield and Utilization}

The cost model also assumes $85 \%$ utilization and $80 \%$ total yield across all country scenarios except in the China Tier 2 scenario. A 90\% utilization and 70\% total yield are assumed for the China Tier 2 scenario due to lower automation levels modeled in that scenario. This also impacts China Tier 2 equipment pricing (slightly lower due to less sophisticated equipment) and labor costs (slightly higher due to less automated processes) when compared to China Tier 1. 


\section{Results and Discussion}

\section{Modeled Cost}

The data and assumptions used to model all costs and MSPs presented here were collected in 2014 and early 2015; as such, the results are intended to be representative of the conditions in 2014 and early 2015.

Materials represent the largest share of total cell cost $-74 \%$ on average across all scenarios modeled. Of this, four materials represent $75 \%$ of total material costs: cathode active materials, here modeled as NMC (32\%), separator (18\%); electrolyte (16\%); and anode active materials, here modeled as graphite (11\%). Other materials each comprise less than $10 \%$ of the total materials cost. The average modeled material cost breakdown across all regions is shown in Figure 5.

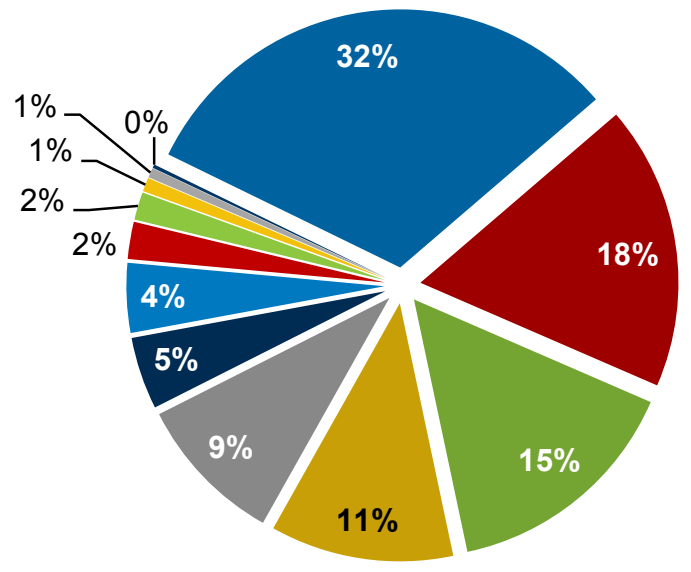

$$
\begin{aligned}
& \text { - Cathode active } \\
& \text { - Separator } \\
& \text { Electrolyte } \\
& \square \text { Anode active } \\
& \square(\text { Cu) Current collector } \\
& \text { - (pos) Current collector } \\
& \square \text { Terminals } \\
& \text { (pos) Slurry } \\
& \text { Pouch } \\
& \square \text { Conductor } \\
& \text { Conductive additive } \\
& \text { (neg) Slurry }
\end{aligned}
$$

Figure 5. Average modeled material cost breakdown

Cell cost breakdowns by country scenario are presented in Figure 6. By comparing the highest and lowest total cost scenarios (U.S. Startup vs. China Tier 1), it appears that the differences in materials ( $\$ 202$ vs. $\$ 168$ ) and labor (\$28 vs. \$2) costs drive the majority of the difference between the scenarios. 


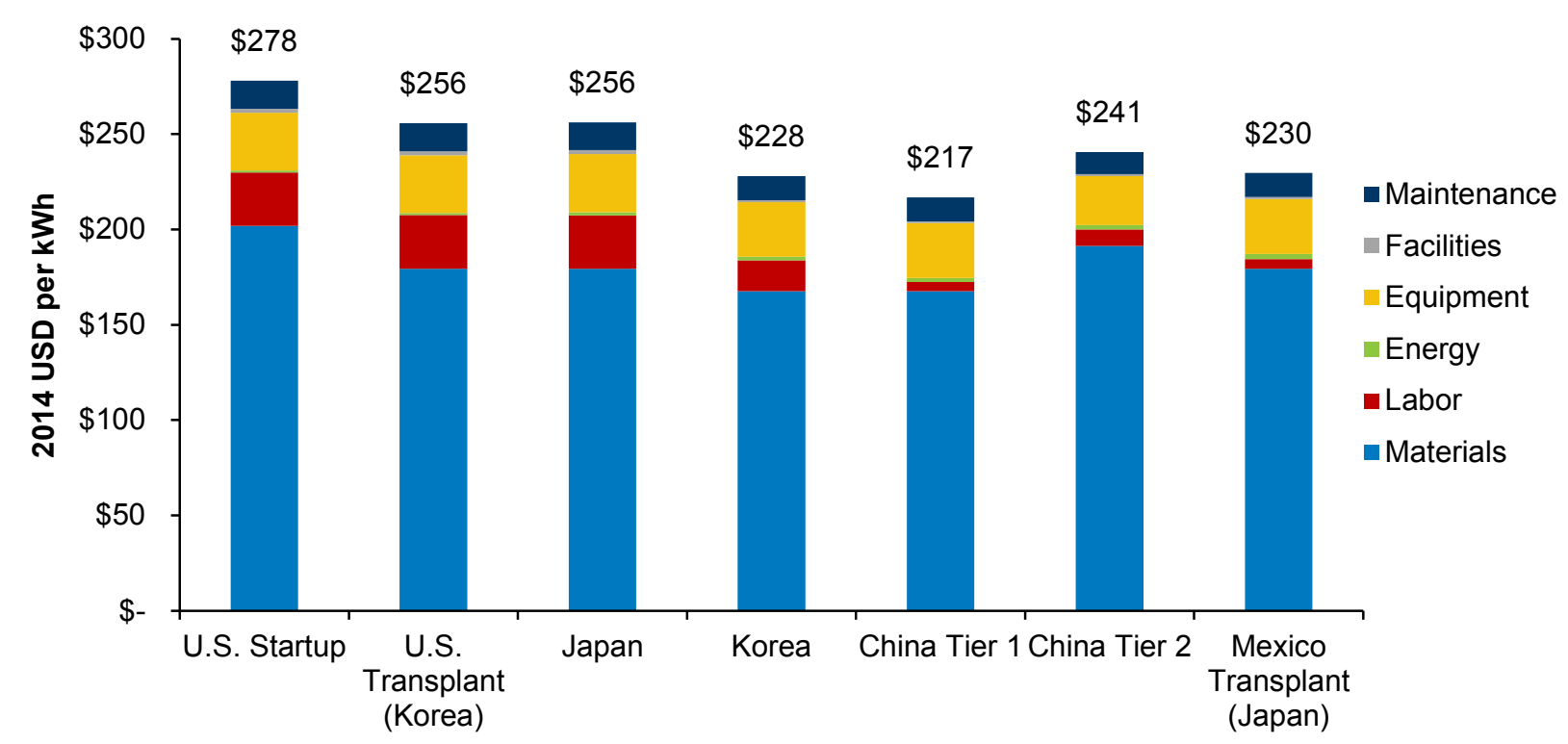

Figure 6. Modeled cost across all regions

Though we are not aware of any significant LIB manufacturing in Mexico, we include a Mexico scenario for purposes of comparison because it is geographically close to U.S. markets and because its labor rates are lower than the United States and approximately equivalent to labor rates in China. This scenario is intended to represent not only the potential competitiveness of Mexican production, but also what might be possible if any country were able to reproduce the combination of advantages (low labor and capital costs) modeled in that scenario.

\section{Modeled Minimum Sustainable Price}

Prices shown are modeled MSPs, which are the minimum prices a manufacturer must charge in order to earn a return equal to their cost of capital. Actual market pricing is also influenced by firm specific strategies and market conditions. Although the overall modeled cost structure for a possible Mexican LIB plant is slightly higher than that for China Tier 1 and Korea scenarios, the sustainable pricing achievable in the Mexico scenario is the lowest of all scenarios, as shown in Figure 5. 


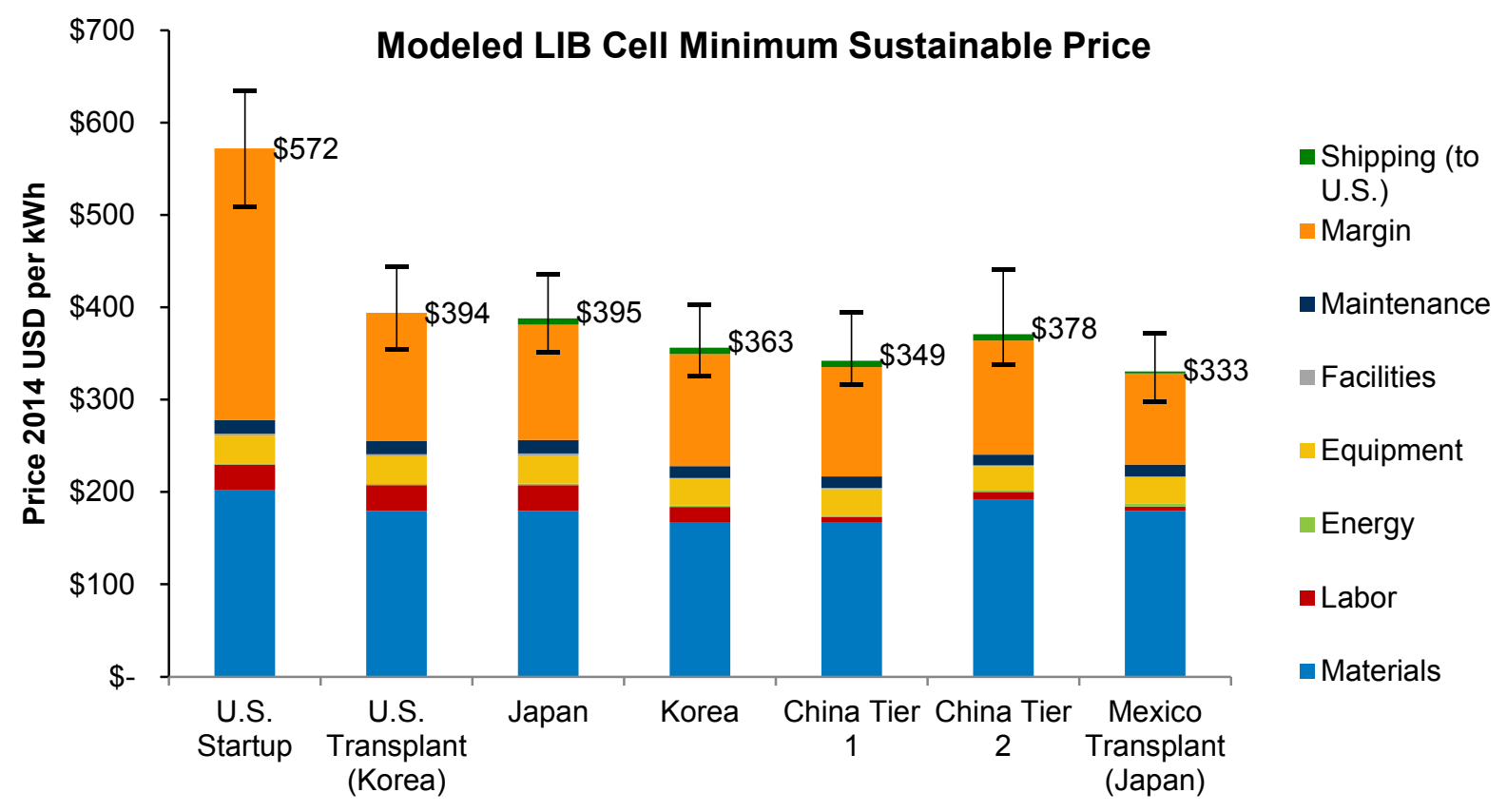

Figure 7. Modeled MSP

Mexico's lowest sustainable price is driven by a combination of a competitive total cost structure and a low WACC due to the assumption of a Japanese parent company. The China Tier 1 and Korea scenarios constitute the next lowest tier of sustainable prices, with modeled prices being within $\sim 3 \%$ of each other. This is an unsurprising result, given that companies from these regions currently dominate LIB cell markets, along with Japanese firms. The U.S. scenarios lag behind the other scenarios due to slightly higher costs for materials, labor, and facilities, and U.S. manufacturers also require relatively high returns. The U.S. Startup scenario in particular reflects the difficulty of competing with a $14 \%$ cost of capital and corresponding high margin requirements. ${ }^{3}$

\section{Considerations for U.S.-Based Manufacturing}

While the prices for the U.S. representative scenarios modeled are higher than for other modeled scenarios, U.S. pricing could possibly be competitive with current minimum sustainable pricing from low-cost producer nations such as Korea and China. ${ }^{4}$ We use our model to demonstrate that this could be achieved if material costs are equalized with the Korea and China Tier 1 representative scenarios (which benefit both for volume and local materials discounts) and an $8 \%$ cost of capital is assumed. While equalizing material costs might require an established domestic supply chain, the cost of capital assumption appears possible even today. Using two established U.S.-based battery manufacturers (Johnson Controls and

\footnotetext{
${ }^{3}$ The cost of capital for this scenario was developed using actual financial data from U.S. automotive battery startup company $\mathrm{A} 123$ when it was an independent, publicly traded firm.

${ }^{4} \mathrm{By}$ 'competitive', we assume pricing within $5 \%$ of representative price leaders (in this case, China Tier 1 ).
} 
Energizer) as comparables suggests that an average WACC of $8.3 \%$ appears to be possible for U.S. companies engaged in the battery sector.

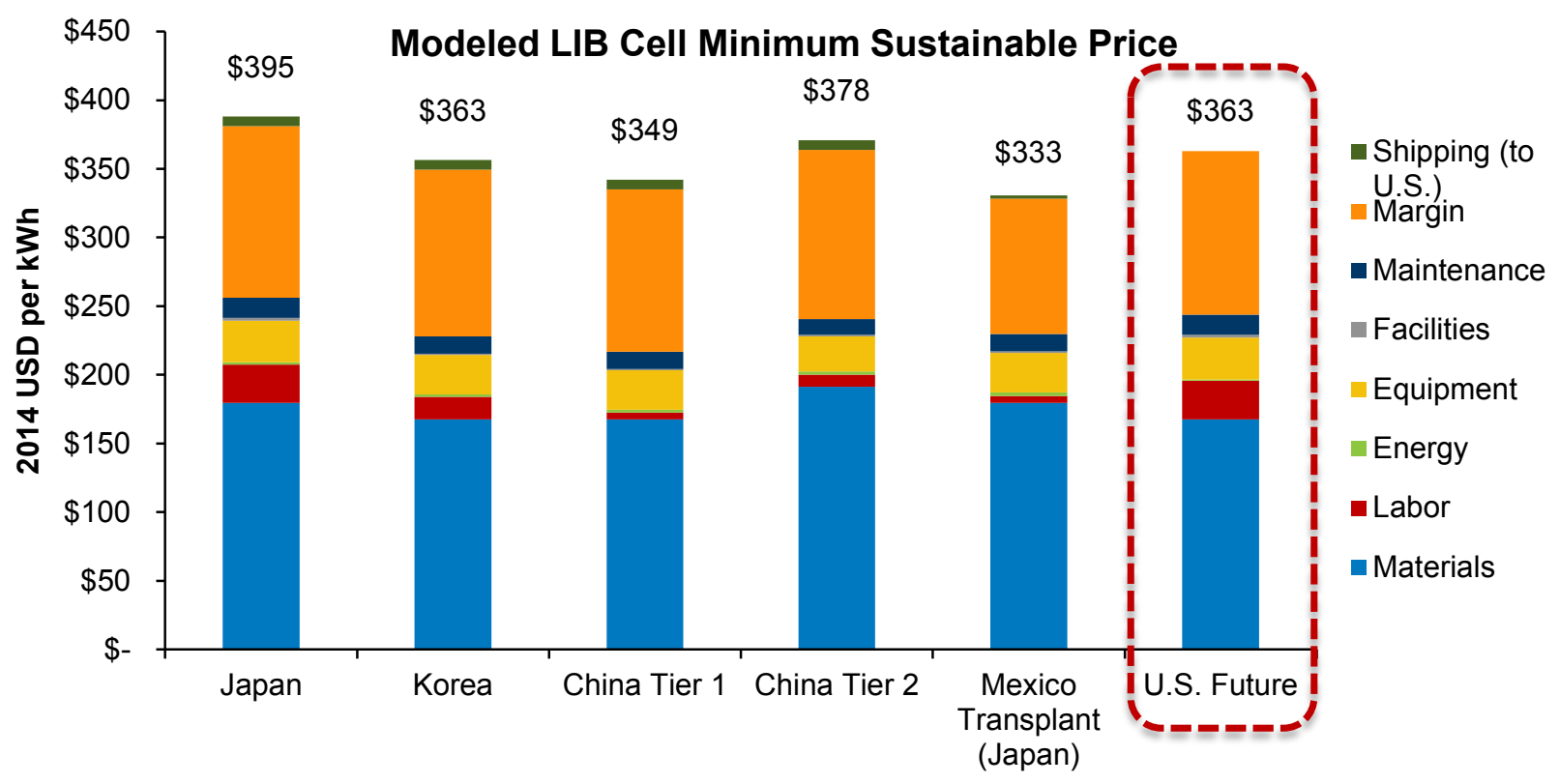

Figure 8. Modeled minimum sustainable price, U.S. Future scenario

Moreover, indirect cost and qualitative factors not captured in this model could incentivize U.S.-based LIB manufacturing, including the following (Porter and Rivkin 2012; World Bank 2013):

- Policy and regulatory contexts

- Ease-of-doing-business considerations

- Logistical risks and proximity to end markets

- Protection of intellectual property, including process innovations

- Supply chain optimization (may include vertical integration)

- Brand and reputation

- Access to talented workforce, especially to advance RD\&D.

The growth of the electric vehicle market creates opportunity for U.S.-based manufacturers to capture a portion of the automotive LIB market. If XEV production continues in the United States, manufacturers may find opportunity to compete in automotive LIB production. Nonetheless, U.S.-based manufacturing faces difficult challenges given its disadvantages in various cost categories and the current relative immaturity of the U.S. supply chain and market participants. 


\section{Other Cost and Price Drivers}

\section{Yield and Utilization}

Although yield and utilization were kept constant in the model (with the exception of China Tier 2), actual utilizations and yields likely vary significantly among firms, even among those within the same country. The impacts of yield and utilization on the MSP are shown in Figure 9.

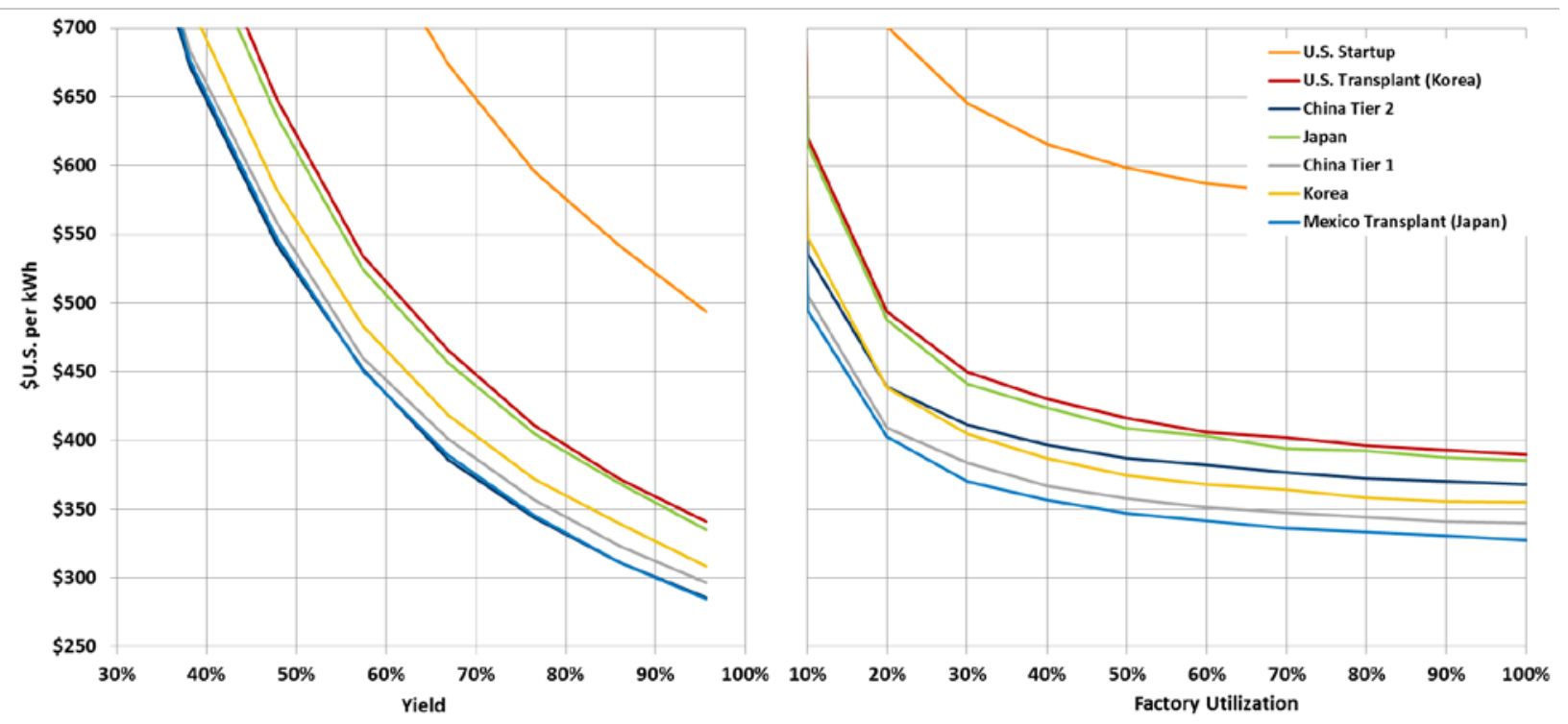

Figure 9. Modeled cell price vs. yield and utilization

Yields are likely a function of cumulative production experience in small and large format LIB cell production. NREL interviews suggest that large format LIB cell yields range between $70 \%-$ $90 \%$. This range can be attributed to the difficulty associated with precisely and consistently controlling the electrochemical reactions utilized in the battery manufacturing process. The range is also due in part to the relative immaturity of the industry itself (specifically in producing large format cells), and the diversity of experience levels various competitors possess. Incumbent firms likely achieve the higher end of this range or greater due to their experience gained from LIB production for consumer electronics applications, although large format cells can present some unique challenges. Higher yields are one way Japanese firms with relatively high cost structures may be able to compete effectively against rivals from Korea and China, who generally enjoy lower cost structures but may also sustain lower yields. In manufacturing, yield advantages are typically fleeting and diminish as competitors improve their yields as their cumulative production volumes increase.

Utilization today is particularly uncertain at the firm level due to overall overcapacity. While price is less sensitive to utilization than yield, utilization still has a material effect, especially at particularly low values. Global average utilization was estimated at 22\% in 2014 (BNEF Desktop Portal 2014; Anderman 2013; NREL estimates), suggesting some firms were operating below this point, where the effect upon MSP is most severe. 


\section{Market Considerations}

We note that actual selling prices may be driven by market factors other than manufacturing costs, especially in early stages of high-growth industries such as large format LIB cells. For example, due to the relative immaturity of large format LIBs, manufacturers may have initially rated the cells below their actual capacities in order to ensure products would meet or exceed their marketed specifications. This had the effect of increasing the marketed capacity normalized price $(\$ / \mathrm{kWh})$. Additionally, global overcapacity of LIB cell production may have led manufacturers to price products below MSP. The MSP modeled in this analysis is based on cost structure and financial parameters, and is intended to reflect long-term market clearing prices assuming a mature, balanced, and rational market.

\section{Cells in the Context of Total LIB Supply Chain}

Major components of the automotive LIB value chain include processed materials for electrodes and other components, cell manufacturing, and pack manufacturing. With respect to vertical integration, various manufacturers are employing different approaches. Pack design and production is typically performed by automakers themselves (AAB 2014) today. In contrast, LIB electrode materials, other processed materials, and complete sealed cells can be shipped without significant cost penalty relative to current market prices, and can often occur in locations separate from pack production. The ability to ship these goods suggests that regions and firms producing competitively priced cells, components, and processed materials can effectively serve global markets. 


\section{Conclusion}

Factors driving the cost competitiveness of LIB manufacturing locations are mostly built, though some regional costs are significant and should be considered. We have discussed a wide variety of regional cost factors, including the cost of capital, labor, and policies, while built advantages include supply chain developments and competition, access to materials, and production expertise.

The majority of automotive LIB cell production is currently located in Asia, and is owned by firms with extensive experience in producing LIB cells for consumer electronics markets. Such incumbent competitors leverage significant advantages when competing in the automotive market, which include robust supply chains and leverage over suppliers, strategic partnerships and more diversified sales channels, higher yields, and other advantages stemming from manufacturing learning effects. However, while Asian firms currently dominate the market, price competitive production may be possible from Mexican and U.S. manufacturing locations given materials pricing equivalent to that achieved by cost leaders and an $8 \%$ WACC.

Market factors beyond incumbency, built, and regionally driven cost advantages can also affect actual observed pricing, especially during the early, relatively volatile stages of industry growth. Current automotive LIB production capacity is underutilized, affecting the unit cost of production and potentially impacting market prices and capacity investment decisions. Further, firms may be currently pursuing strategies and location decisions that only partially integrate regional cost considerations. As the automotive LIB market stabilizes and rationalizes, more straightforward cost-based pricing trends may emerge. 


\section{References}

Alexander, David, and John Gartner. 2013. "Electric Vehicle Batteries." Boulder, CO: Pike Research.

Alexander, David, and John Gartner. 2014. "Electric Vehicle Batteries." Boulder, CO: Navigant Consulting.

Anderman, Menahem. 2013. "Will Advances in Battery Technology Be Sufficient to Sustain the PHEV/EV Market?" Presented at the AABTAM Symposium.

AAB (Advanced Automotive Batteries). 2014. Assessing the Future of Hybrid and Electric Vehicles: The xEV Industry Insider Report. Oregon House, CA: Advanced Automotive Batteries.

Behl, Jiten. 2015. "Automotive Lithium-Ion Batteries - Status and Outlook." presented at the The Battery Show, Novi, MI, September 15.

BNEF (Bloomberg New Energy Finance) Desktop Portal. 2016. https://www.bnef.com/core/.

Coy, P. 2013. "Four Reasons Mexico Is Becoming a Global Manufacturing Power." Bloomberg Business. Accessed January 2016, http://www.bloomberg.com/news/articles/2013-06-27/four-reasons-mexico-isbecoming-a-global-manufacturing-power.

Brodd, R. J., and C. Helou. 2013. "Cost Comparison of Producing High-Performance Lithium-ion Batteries in the U.S. and in China." Journal of Power Sources 231: 293-300.

Davis, Stacy, Susan Diegel, Robert Boundy, and Sheila Moore. 2015. 2014 Vehicle Technologies Market Report. ORNL/TM-2015/85. Oak Ridge, TN: Oak Ridge National Laboratory.

http://cta.ornl.gov/vtmarketreport/pdf/2014 vtmarketreport full doc.pdf.

Davis, Stacy. 2013. Vehicle Technologies Market Report. 2013. Oak Ridge, TN: Oak Ridge National Laboratory. Accessed May 14, 2014, http://cta.ornl.gov/vtmarketreport/index.shtml.

Goodrich, A., D. Powell, T. James, M. Woodhouse, and T. Buonassisi. 2013. "Assessing the Drivers of Regional Trends in Solar Photovoltaic Manufacturing." Energy \& Environmental Science 6: 2811-2821.

Haley, Usha C.V. 2012. Putting the Pedal to the Metal: Subsidies to China's Auto-Parts Industry from 2001 to 2011. Economic Policy Institute Briefing Paper \#316. Economic Policy Institute. Accessed January 5, 2015, http://www.epi.org/publication/bp316-china-auto-parts-industry/.

IEA (International Energy Agency). “Global EV Outlook 2015 Update.” 2015.

http://www.iea.org/evi/Global-EV-Outlook-2015-Update_1page.pdf.

“Mexico vs. China Manufacturing." 2014. TACNA Services. Accessed January 2016, http://tacna.net/mexico-vs-china/.

Powell, D., M. Winkler, A. Goodrich, and T. Buonassisi. 2013. "Modeling the Cost and Minimum Sustainable Price of Crystalline Silicon Photovoltaic Manufacturing in the United States." IEEE Journal of Photovoltaics 3(2): 662-668. 
Shepard, Scott, and Lisa Jerram. 2015. "Transportation Forecast: Light Duty Vehicles." Boulder, CO: Navigant Consulting, Inc.

Stewart, Terence P., Elizabeth J. Drake, Philip A. Butler, Jumana Misleh, Ping Gong, Jessica Wang, Ni Y. Meggers, and David DePrest. 2012. China's Support Programs for Automobiles and Auto Parts Under the $12^{\text {th }}$ Five-Year Plan. Law Offices of Stewart and Stewart. Accessed January 5, 2015, http://www.stewartlaw.com/Content/Documents/S\%20and\%20S\%20China\%20Auto\%20Parts\%20Subsi dies\%20Report.pdf.

Technavio Insights. 2015. "Global Li Ion Battery Market for All Electric Vehicles (AEVs)." Market Research Report.

Tesla (Tesla Motors Inc.). 2016. Tesla Motors Inc. Form 10-K Annual Report for the Period Ending 12/31/15. Palo Alto, CA: Tesla. Accessed March 2016, http://files.shareholder.com/downloads/ABEA4CW8X0/1709716704x0xS1564590-16-13195/1318605/filing.pdf.

"UPDATE 1-Mexico hourly wages now lower than China's-study." 2014. Reuters. Accessed January 2016, http://www.reuters.com/article/economy-mexico-wages-idUSL2NOCR1TY20130404.

Venkataraman, Sreekanth, and John Gartner. 2011. "Electric Vehicle Batteries." Boulder, CO: Pike Research.

Wall Street Journal: China Realtime. 2014. "As China's Economy Slows, So Too Does Growth in Workers' Wages." Accessed January 2016, http://blogs.wsj.com/chinarealtime/2014/12/17/as-chinas-economyslows-so-too-does-growth-in-workers-wages/.

Wessner, Charles W., and Alan Wm. Wolff, eds. 2012. Rising to the Challenge: U.S. Innovation Policy for the Global Economy - National Research Council (US) Committee on Comparative National Innovation Policies: Best Practice for the 21st Century. Comparative Innovation Policy. Washington, D.C.: The National Academies Press. Accessed December 2014, http://www.ncbi.nlm.nih.gov/books/NBK100307/\#ch6.s30.http://www.ncbi.nlm.nih.gov/books/NBK100 307/\#ch6.s30. 


\section{Appendix}

Key assumptions for the model scenarios are documented in this appendix, including key assumptions regarding country scenarios and input material costs.

Table A-1. Key Assumptions, Country Scenarios

\begin{tabular}{|c|c|c|c|c|c|c|c|c|}
\hline & & U.S. Startup & $\begin{array}{c}\text { U.S. } \\
\text { Transplant }\end{array}$ & Japan & Korea & Tier 1 China & Tier 2 China & Mexico \\
\hline & unit & $\begin{array}{l}\text { U.S.-Based New } \\
\text { Entrant }\end{array}$ & $\begin{array}{c}\text { Korea Owned, } \\
\text { U.S. Factory }\end{array}$ & $\begin{array}{l}\text { Japan Owned, } \\
\text { Japan Factory }\end{array}$ & $\begin{array}{l}\text { Korea Owned, } \\
\text { Korea Factory }\end{array}$ & $\begin{array}{l}\text { China Owned, } \\
\text { China Factory }\end{array}$ & $\begin{array}{l}\text { China Owned, } \\
\text { China Factory }\end{array}$ & $\begin{array}{l}\text { Japan Owned, } \\
\text { Mexico Factory }\end{array}$ \\
\hline Unskilled Cost of Wages ${ }^{1}$ & $\$ / h r$ & $\$ 18.73$ & $\$ 18.73$ & $\$ 18.55$ & $\$ 10.88$ & $\$ 3.34$ & $\$ 3.34$ & $\$ 3.34$ \\
\hline Skilled Cost of Wages ${ }^{2}$ & $\$ / h r$ & $\$ 26.95$ & $\$ 26.95$ & $\$ 26.70$ & $\$ 15.65$ & $\$ 13.41$ & $\$ 13.41$ & $\$ 13.41$ \\
\hline Cost of Salary ${ }^{3}$ & $\$ / y r$ & $\$ 90,365$ & $\$ 90,365$ & $\$ 89,529$ & $\$ 52,491$ & $\$ 16,112$ & $\$ 16,112$ & $\$ 16,112$ \\
\hline Indirect:Direct Labor Ratio & & 0.35 & 0.35 & 0.35 & 0.35 & 0.35 & 0.35 & 0.35 \\
\hline Working Days per Year & days/yr & 350 & 350 & 350 & 350 & 350 & 350 & 350 \\
\hline Working Hours per Day & hrs/day & 24 & 24 & 24 & 24 & 24 & 24 & 24 \\
\hline $\begin{array}{r}\text { Weighted Average Cost of } \\
\text { Capital }^{4}\end{array}$ & $\%$ & $14.3 \%$ & $10.3 \%$ & $7.0 \%$ & $10.6 \%$ & $11.4 \%$ & $11.4 \%$ & $7.2 \%$ \\
\hline Price of Electricity 5 & $/ k W h$ & $\$ 0.040$ & $\$ 0.040$ & $\$ 0.070$ & $\$ 0.070$ & $\$ 0.077$ & $\$ 0.077$ & $\$ 0.107$ \\
\hline Price of Natural Gas 6 & $/ m^{3}$ & $\$ 0.00026$ & $\$ 0.00026$ & $\$ 0.00103$ & $\$ 0.00051$ & $\$ 0.00051$ & $\$ 0.00051$ & $\$ 0.00026$ \\
\hline Price of Building Space ${ }^{7}$ & $/ m^{2}$ & $\$ 1,700$ & $\$ 1,700$ & $\$ 1,700$ & $\$ 805$ & $\$ 805$ & $\$ 805$ & $\$ 805$ \\
\hline Equipment Installation Costs 8 & $\%$-equipment & $12.0 \%$ & $12.0 \%$ & $12.0 \%$ & $6.0 \%$ & $6.0 \%$ & $6.0 \%$ & $6.0 \%$ \\
\hline Equipment Discount ${ }^{9}$ & \%-equipment & $0.0 \%$ & $0.0 \%$ & $0.0 \%$ & $0.0 \%$ & $0.0 \%$ & $35.0 \%$ & $0.0 \%$ \\
\hline Corporate Tax Rate R $^{10}$ & $\%$ & $40.0 \%$ & $40.0 \%$ & $35.6 \%$ & $24.2 \%$ & $25.0 \%$ & $25.0 \%$ & $30.0 \%$ \\
\hline$S G \& A^{11}$ & $\%$-revenues & $12.3 \%$ & $12.3 \%$ & $12.3 \%$ & $12.3 \%$ & $12.3 \%$ & $12.3 \%$ & $12.3 \%$ \\
\hline$R \& D^{12}$ & $\%$-revenues & $20.0 \%$ & $3.5 \%$ & $3.5 \%$ & $3.5 \%$ & $3.5 \%$ & $1.8 \%$ & $3.5 \%$ \\
\hline Expected inflation $^{13}$ & $\%$ & $2.0 \%$ & $2.0 \%$ & $1.9 \%$ & $2.7 \%$ & $2.9 \%$ & $2.9 \%$ & $3.7 \%$ \\
\hline Total Yield ${ }^{14}$ & $\%$ & $80 \%$ & $80 \%$ & $80 \%$ & $80 \%$ & $80 \%$ & $70 \%$ & $80 \%$ \\
\hline Automation & & Yes & yes & yes & yes & yes & no & yes \\
\hline Electrode line speed & $\mathrm{m} / \mathrm{min}$ & 20 & 20 & 20 & 20 & 20 & 10 & 20 \\
\hline
\end{tabular}


${ }^{1}$ Bureau of Labor Statistics, 51-9198 Helpers-Production Workers, http://www.bls.gov/OES/current/oes519198.htm\#ind

2 Bureau of Labor Statistics, 51-9141 Semiconductor Processors, http://www.bls.gov/oes/current/oes519141.htm

${ }^{3}$ Bureau of Labor Statistics, 51-1011 First-Line Supervisors of Production and Operating Workers, http://www.bls.gov/oes/current/oes511011.htm

Note: International Labor rates adjusted by international manufacturing labor rates, http://www.bls.gov/fls/ichcc.pdf

${ }^{4}$ Public financial data accessed from Bloomberg Terminal for the following companies: Wanxiang Qianchao, BYD Co Ltd, Panasonic, Hitachi, NEC Corp, Toshiba, Samsung SDI, LG Chem, SK Innovation, Johnson Controls, Energizer; accessed December 2014

${ }^{5}$ Energy Information Agency, Washington state for industrial customers, http://www.eia.gov/electricity/data.cfm\#sales; Korea - Bloomberg, http://www.bloomberg.com/news/2013-01-09/south-korea-increases-power-prices-second-time-to-curb-demand.html; China: Bloomberg, http://www.bloomberg.com/news/2011-05-30/china-raises-industrial-power-prices-in-15-provinces-to-help-ease-shortage.html; Mexico - Secretaria De Energia, http://www.sener.gob.mx/portal/Mobil.aspx?id=1606

${ }^{6}$ Energy Information Agency, http://www.eia.gov/todayinenergy/detail.cfm?id=3310

7 Brodd 2012

8 CEMAC estimate

${ }^{9}$ CEMAC estimate assuming less automated, lower throughput equipment

${ }^{10}$ Tax rates from KPMG, http://www.kpmg.com/global/en/services/tax/tax-tools-and-resources/pages/corporate-tax-rates-table.aspx

11 Public financial data accessed from Bloomberg Terminal for the following companies: Wanxiang Qianchao, BYD Co Ltd, Panasonic, Hitachi, NEC Corp, Toshiba, Samsung SDI, LG Chem, SK Innovation, Johnson Controls, Energizer; accessed December 2014

12 Public financial data accessed from Bloomberg Terminal for the following companies: Wanxiang Qianchao, BYD Co Ltd, Panasonic, Hitachi, NEC Corp, Toshiba, Samsung SDI, LG Chem, SK Innovation, Johnson Controls, Energizer; accessed December 2014

${ }^{13}$ PriceWaterhouseCoopers, http://www.pwc.com/gx/en/issues/economy/global-economy-watch/projections/june-2014.jhtml .

${ }^{14}$ Confidential conversation with industry. 
Table A-2. Key Assumptions, Materials Costs

\begin{tabular}{|c|c|c|c|c|c|c|c|c|c|}
\hline & & & U.S. Startup & U.S. Transplant & Japan & Korea & Tier 1 China & Tier 2 China & Mexico \\
\hline Part & Description & unit & $\begin{array}{c}\text { U.S.-Based New } \\
\text { Entrant }{ }^{4}\end{array}$ & $\begin{array}{l}\text { Korea Owned, } \\
\text { U.S. Factory }\end{array}$ & $\begin{array}{l}\text { Japan Owned, } \\
\text { Japan Factory }\end{array}$ & $\begin{array}{l}\text { Korea Owned, } \\
\text { Korea Factory }\end{array}$ & $\begin{array}{l}\text { China Owned, } \\
\text { China Factory }\end{array}$ & $\begin{array}{l}\text { China Owned, } \\
\text { China Factory }\end{array}$ & $\begin{array}{l}\text { Japan Owned, } \\
\text { Mexico Factory }\end{array}$ \\
\hline \multirow[t]{2}{*}{ Anode active material } & \multicolumn{2}{|c|}{ Natural graphite (carbon coated) USD/ kg } & $\$ 14.87$ & $\$ 14.87$ & $\$ 14.87$ & $\$ 13.09^{1}$ & $\$ 13.09^{1}$ & $\$ 13.09^{1}$ & $\$ 14.87$ \\
\hline & Synthetic graphite & USD/kg & $\$ 18.00$ & $\$ 18.00$ & $\$ 18.00$ & $\$ 15.84^{1}$ & $\$ 15.84^{1}$ & $\$ 15.84^{1}$ & $\$ 18.00$ \\
\hline Binder & SBR (5.0 wgt- $\%)$ & USD/kg & $\$ 6.00$ & $\$ 5.52^{2}$ & $\$ 5.52^{2}$ & $\$ 5.52^{2}$ & $\$ 5.52^{2}$ & $\$ 5.52^{2}$ & $\$ 5.52^{2}$ \\
\hline Solvent & Water ( 96 wgt- $\%$ of slurry mix) & USD/kg & $\$$ & $\$$ & $\$$ & $\$$ & $\$$ & $\$$ & $\$$ \\
\hline Current collector & 12 um Rolled Copper & $\mathrm{USD} / \mathrm{m}^{2}$ & $\$ 1.80$ & $\$ 1.66^{2}$ & $\$ 1.66^{2}$ & $\$ 1.66^{2}$ & $\$ 1.66^{2}$ & $\$ 1.66^{2}$ & $\$ 1.66^{2}$ \\
\hline Cathode active material & NMC333-G (89 wgt-\%) & USD/kg & $\$ 30.00$ & $\$ 24.00^{3}$ & $\$ 24.00^{3}$ & $\$ 20.10^{3}$ & $\$ 20.10^{3}$ & $\$ 18.00^{3}$ & $\$ 24.00^{3}$ \\
\hline Conductive materials & Carbon black (6 wgt- $\%$ ) & USD/kg & $\$ 7.50$ & $\$ 6.90^{2}$ & $\$ 6.90^{2}$ & $\$ 6.90^{2}$ & $\$ 6.90^{2}$ & $\$ 6.90^{2}$ & $\$ 6.90^{2}$ \\
\hline Binder & PVDF (5 wgt-\%) & USD/kg & $\$ 30.00$ & $\$ 27.60^{2}$ & $\$ 27.60^{2}$ & $\$ 27.60^{2}$ & $\$ 27.60^{2}$ & $\$ 27.60^{2}$ & $\$ 27.60^{2}$ \\
\hline Solvent & NMP ( 96 wgt- $\%$ of slurry mix) & USD/kg & $\$ 18.00$ & $\$ 16.56^{2}$ & $\$ 16.56^{2}$ & $\$ 14.40^{1,2}$ & $\$ 14.40^{1,2}$ & $\$ 14.40^{1,2}$ & $\$ 16.56^{2}$ \\
\hline Current collector & 20 um Aluminum & $\mathrm{USD} / \mathrm{m}^{2}$ & $\$ 0.80$ & $\$ 0.74^{2}$ & $\$ 0.74^{2}$ & $\$ 0.74^{2}$ & $\$ 0.74^{2}$ & $\$ 0.74^{2}$ & $\$ 0.74^{2}$ \\
\hline \multirow[t]{2}{*}{ Separator } & 20 um PP (uncoated) & $\mathrm{USD} / \mathrm{m}^{2}$ & $\$ 2.00$ & $\$ 1.84^{2}$ & $\$ 1.84^{2}$ & $\$ 1.84^{2}$ & $\$ 1.84^{2}$ & $\$ 1.84^{2}$ & $\$ 1.84^{2}$ \\
\hline & 20 um PVDF based & $\mathrm{USD} / \mathrm{m}^{2}$ & $\$ 5.00$ & $\$ 4.60^{2}$ & $\$ 4.60^{2}$ & $\$ 4.60^{2}$ & $\$ 4.60^{2}$ & $\$ 4.60^{2}$ & $\$ 4.60^{2}$ \\
\hline Electrolyte & EC/DMC/MEC-LiPF6 & USD/kg & $\$ 19.57$ & $\$ 18.00^{2}$ & $\$ 18.00^{2}$ & $\$ 18.00^{2}$ & $\$ 18.00^{2}$ & $\$ 18.00^{2}$ & $\$ 18.00^{2}$ \\
\hline
\end{tabular}

${ }^{1}$ Local production cost discount from cluster effects and policy interventions $-12 \%$ for all regions where applied

${ }^{2}$ Volume discount $-8 \%$ for all regions where applied

${ }^{3}$ NMC discounts driven by volume purchasing, and from cluster effects and policy interventions - 20\% for U.S. Transplant, Japan, and Mexico; $33 \%$ for Korea and China Tier 1 ; $40 \%$ for China Tier 2

${ }^{4}$ Base cost from ANL's BatPak, http://www.cse.anl.gov/batpac/. 